\title{
Temporal and spatial changes in Myotis lucifugus acoustic activity before and after white-nose syndrome on Fort Drum Army Installation, New York, USA
}

\author{
Tomas Nocera ${ }^{1}$, W. Mark Ford ${ }^{2,5}$, Christopher Dobony ${ }^{3}$, and Alexander Silvis ${ }^{4}$ \\ ${ }^{1}$ Virginia Polytechnic Institute and State University, Department of Fish and Wildlife Conservation, 149 Cheatham Hall, \\ Virginia Tech, Blacksburg, VA 24061, USA \\ ${ }^{2}$ US Geological Survey, Virginia Cooperative Fish and Wildlife Research Unit, 106 Cheatham Hall, Blacksburg, VA 24061, USA \\ ${ }^{3}$ Fort Drum Military Installation, Directorate of Public Works, Natural Resource Branch, T-4848 Delahanty Ave., Fort Drum, \\ NY 13602-5097, USA \\ ${ }^{4}$ West Virginia Division of Natural Resources, Box 67, Elkins WV 24261, USA \\ ${ }^{5}$ Corresponding author: E-mail: wmford@vt.edu
}

\begin{abstract}
Changes to bat distribution and habitat associations at the local to sub-landscape scale in the post white-nose syndrome (WNS) environment have received little attention to date despite being critical information for managers. To better understand the spatial nature of bat population declines, we modelled both activity patterns and occupancy from acoustic surveys for the Myotis lucifugus (little brown bat) on Fort Drum Military Installation in New York, USA over 15 summers (2003-2017) that span the pre-WNS, WNS-advent (2008) and post-WNS periods, using a set of generalized linear mixed models and geospatial analysis. Our best supported model indicated significant differences between years with significant declines in activity post-WNS. M. lucifugus activity was most closely associated with woody wetland habitats over the study period, however, the spatial patterns of high activity areas were variable over years, with the areal extent of these high activity areas decreasing post-WNS. Our best supported occupancy model varied by year. However, the null occupancy model $[\Psi()$.$] was either competing (within 2 \Delta$ AIC units) or was the best supported model. Meaning that none of our environmental variables seemed to impact occupancy, and when they did, these differences were not significant. There was high disagreement between our relative activity models and predictions compared to our occupancy models, suggesting that geographic spatial scale and the resolution of the data impacts model outcome. Our results indicate that continued acoustic monitoring of bat species in the Northeast to assess ongoing temporal and spatial changes in habitat associations and to provide direction for future mist-netting studies should rely more on relative activity as the metric of choice rather than site occupancy.
\end{abstract}

Key words: acoustic monitoring, GIS, Myotis lucifugus, occupancy model, relative activity, white-nose syndrome

\section{INTRODUCTION}

The fungal pathogen, Pseudogymnoascus destructans, causative agent of white-nose syndrome (WNS), was first documented in the United States in 2006 in upstate New York, U.S.A (Blehert et al., 2009). Since then, the disease agent has moved rapidly throughout the Northeast, mid-South and Midwest, as well as throughout much of eastern and south-central Canada (U.S. Geological Survey, 2019). WNS has been found to infect eight species of cave-dwelling bats in eastern North America: the federally endangered Myotis sodalis (Indiana bat), the federally threatened M. septentrionalis (Northern long-eared bat), M. leibii (Eastern small-footed bat), M. lucifugus (little brown bat), the federally endangered $M$. grisescens (gray bat), $M$. austroriparius (Southeastern bat), Eptesicus fuscus (big brown bat), and Perimyotis subflavus (tri-colored bat). Infecting the epidermis of hibernating bats, the fungus causes abnormal frequent arousal through winter leading to loss of critical fat reserves and disruption of water balance (Cryan et al., 2010; Frick et al., 2010; Meteyer et al., 2012).

Among impacted species, M. lucifugus, $M$. septentrionalis, $M$. sodalis, and $P$. subflavus have had the most dramatic changes in activity patterns, abundance, and distribution (Blehert et al., 2009; Frick et al., 2010; Brooks, 2011; Ford et al., 2011). Prior to the onset of WNS, populations of M. lucifugus were either stable or increasing, and was one of the most common and abundant bats in North 
America. Yet, since the discovery of WNS, populations of $M$. lucifugus have declined precipitously, with estimates of loss being greater than $90 \%$ in the Northeast (Frick et al., 2010; Dzal et al., 2011; Jachowski et al., 2014a; Ingersoll et al., 2016). Some individuals of M. lucifugus do show healed wing membranes, post-winter survival, and reproduction after infection by $P$. destructans (Dobony et al., 2011; Dobony and Johnson, 2018). However, significant mortality throughout the winter, poor female physiological condition, and energetic demands to repair dermal tissue have resulted in reproductive rates to become variable, limiting population recovery (Dzal et al., 2011; Francl et al., 2012; Langwig et al., 2012). As a result, pre-WNS trends of activity levels increasing in mid-summer that are consistent with summer recruitment and reproduction, post-WNS often have declined (Ford et al., 2011). Moreover, WNS impacts have been shown to significantly modify the spatial and temporal niche partitioning among bat communities, resulting from the elimination in interspecific competition of WNS-impacted bat species with those unaffected. Specifically, the reduction in M. lucifugus has been followed by an activity increase of non-WNS affected species that can utilize the spatial and temporal conditions that $M$. lucifugus favor (Jachowski, $2014 a$ ). This dramatic change in population size in a relatively short time frame makes $M$. lucifugus a good model species to evaluate inter- and intraspecific interactions, and their relationship with environmental conditions.

The scarcity of data encompassing pre-WNS and post-WNS years for most positive WNS regions has made it difficult to compare the relative change in bat activity and occupancy between the two periods. However, extensive long term, mist-netting and acoustic monitoring of bat activity, occupancy, and distribution at Fort Drum Military Installation (Fort Drum) in northern New York is an exception (Ford et al., 2011). Much of this monitoring began in response to both known hibernacula nearby to the Installation and the presence of the federally endangered $M$. sodalis on the installation during the summer (Jachowski et al., 2014b). Continuous monitoring from 2003 to present has allowed researchers to document changes in bat numbers, activity, and physiological status between pre- and post-WNS time periods (Dobony et al., 2011; Ford et al., 2011; Coleman et al., 2014a, 2014b, 2014c; Dobony and Johnson, 2018). Previous acoustic surveys and mist-netting has shown that overall activity patterns have shifted among all species between pre- and
post-WNS years at Fort Drum. However, the significance of these changes is based on the species-specific susceptibility to WNS, with M. septentrionalis, $M$. sodalis, and $M$. lucifugus bat activity patterns decreasing the most in the years subsequent to WNS presence (Dobony et al., 2011; Ford et al., 2011). In response to the rapid expansion of WNS, and the steep declines in several of these bat species, this long-term monitoring program has provided a unique opportunity to observe and understand the ecological dynamics of a novel invasive disease. Secondly, these data have implications for understanding the impact to threatened and endangered species, how additional species might become endangered, and how land managers could enhance day-roosting and foraging habitat for remaining bats to compensate for WNS impacts.

Understanding the abiotic and biotic processes that affect how and why species are distributed across a landscape is central for researchers and managers studying biological organisms (Miller, 2010). This importance is exacerbated when dealing with rare or declining species, where changing environmental conditions, such as an outbreak of disease, imply ecological consequences to certain species (Rodhouse et al., 2012). Thus, modelling species abundance, occurrence, distribution, and the metrics associated with changes in distribution have been used extensively to address changing populations within a landscape, especially in bats (Jaberg and Guisan, 2001; O'Shea et al., 2003; Ford et al., 2011; Rodhouse et al., 2012). There are two uses of a model: to explain aspects of the real world, i.e., biological processes, and to predict across space and time (Nally, 2000; Borcard et al., 2011; Sainani, 2014). Species distribution models are widely used as predictors of species presence, habitat suitability and range distribution. This technique often is required for natural resource research, management, and conservation (Franklin, 2010). At its basic form, species distribution can be categorized by the presence of a species and the space in which a species occupies (Franklin, 2010; Borcard et al., 2011). This presents challenges to modeling distribution, activity, and occupancy, as communities and individuals exist in complex spatial arrangements and structures. Whereas models may try to predict the distribution, activity, or occupancy of wildlife populations onto a landscape, it is assumed that biotic distributions across different sampling sites are independent from each other (Franklin, 2010; Borcard et al., 2011). This assumption rarely holds true. In reality, neighboring sites share both biotic and 
abiotic factors, i.e., competition, weather events, and dispersal, where upon similarities between sites become more dependent with the decrease in distance between them (Dray et al., 2006; Dormann et al., 2007; Franklin, 2010; Borcard et al., 2011). This spatial autocorrelation can lead to erroneous conclusions about how certain parameters influence species distributions (Franklin, 2010; Borcard et al., 2011). As an example, in modeling species distributions using environmental conditions, without considering spatial autocorrelation, estimates for such covariates may be either over- or underrepresented, diminishing the accuracy of models (e.g., insects González-Megías et al., 2005; birds - Diniz-Filho and Bini, 2005; and mammals - Peakall et al., 2003). As such, components such as scale, size of sampling units, distance between sites, and extent of the study site can interact with ecological processes and patterns that complicate occupancy and distribution modeling efforts (Borcard et al., 2011).

Effective conservation planning at relatively large scales, such as at Fort Drum, require the understanding of the distribution and relative activity of a species, as well as the topographic and land cover characteristics influencing species presence at an individual site (Erickson and West, 2003; Ford et al., 2005). We used M. lucifugus as a model species to study disease dynamics impacts as it relates to local and regional distribution, and in turn, develop practical research and management techniques appropriate for assessing the spatio-temporal changes in bat activity. We predicted that M. lucifugus would show marked declines in activity across Fort Drum over the duration of the study, that residual activity would become increasingly concentrated along riparian systems and that traditional occupancy analysis for a rare, but still widespread species would fail to convey full information on WNS-caused declines.

Accordingly, our major objectives were to 1) identify suitable site characteristics that affect $M$. $l u$ cifugus relative activity; 2) assess spatio-temporal changes in activity across the landscape; 3 ) develop predictive occurrence models for the wider Fort Drum landscape; and 4) determine how relative activity models and predictions compare to standard occupancy analysis and predictions using a highly mobile species as the model organism.

\section{Materials AND Methods}

\section{Study Area}

We conducted our study at Fort Drum Military Installation in Jefferson and Lewis counties in northwestern New York,
USA. Fort Drum is a 43,750 ha U.S. Military Installation situated where the Eastern Ontario Plains, St. Lawrence Valley, Western Adirondack Transition, Indian River Transition, and Black River Valley ecoregions converge. The Niagara Escarpment, which lies 10-15 km west, contains limestone (Karst) formation caves used as winter hibernacula by bats (Ford et al., 2011). Approximately $57 \%$ of the installation (ca. 25,000 ha) was forested with associations of mature northern hardwood types of Acer saccharum (Sugar Maple), Fagus grandifolia (American beech), Fraxinus americana (white ash), and Pinus strobus (white pine). Early successional habitat was dominated by Acer rubrum (red maple), Betula populifolia (gray birch) and Populus tremuloides (quaking aspen). Beaver (Castor canadensis) ponds, small lakes, wet meadows and other wetland systems comprised approximately $20 \%$ of the land cover (ca. 8,000 ha). Extensive development was concentrated within the cantonment area and certain firing ranges encircling the main impact area; only scattered training facilities and other structures were found throughout the relatively undeveloped maneuver areas in the remainder of the installation. Elevations ranged from 125-278 $\mathrm{m}$ a.s.1.

The bat fauna of Fort Drum consists of nine species including: E. fuscus, M. leibii, M. lucifugus, M. septentrionalis, M. sodalis, and Perimyotis subflavus along with three species unaffected by WNS, Lasiurus borealis (Eastern red bat), Lasionycteris noctivagans (silver-haired bat), and Lasiurus cinereus (hoary bat) (Ford et al., 2011; Coleman et al., 2014a, 2014b).

\section{Acoustic Sampling}

To assess M. lucifugus presence and activity, we examined a long-term collection of echolocation recordings from Fort Drum from the summers of 2003-2017 that has been collected by installation managers for ongoing monitoring tasks (Fig. 1). As such, our site selections were not random, but were systemically chosen to represent the range of habitat conditions encountered on Fort Drum and to provide data for regulatory clearance of land management and training activities. Sampling intensity varied across years with repeat site visits for $98 \%$ of locations across the years (Table 1). We excluded individual nights when detectors at individual sites failed to operate completely from sundown to sunrise. From May through early September for all years, we used Anabat II detectors connected to a compact flash-storage zero-crossings analysis-interface module (ZCAIM), as well as SD1 and SD2 detectors using the same transducer model (Titley Electronics, Ballina, NSW, Australia). From 2003-2011, we placed Anabat units in weatherproof boxes, but left the microphone exposed. In 2012 and onwards, we attached a PVC tube to protect the microphone from rain to the weatherproofing boxes (Britzke et al., 2013). Following Ford et al. (2011) and Coleman et al. (2014b, 2014c), we placed each unit on a $1.5 \mathrm{~m}$ tripod and adjusted it so that sound could enter the exposed microphone or later the PVC tube at an angle of $45^{\circ}$ (Weller and Zabel, 2002). Our survey sites primarily were located near features associated with known higher bat activity, such as interior forest canopy gaps, open water, streams, and wetland habitats (Ford et al., 2005, 2006) Additionally, some sites were located along linear features that bats favor for travel (Verboom and Huitema, 1997), such as unimproved, gravel, secondary roads used for regular vehicular traffic or defined dirt, grass, and/or gravel trails used for military training and recreational use. Detectors were positioned to face road/trail corridors, forest canopy gaps or towards more 


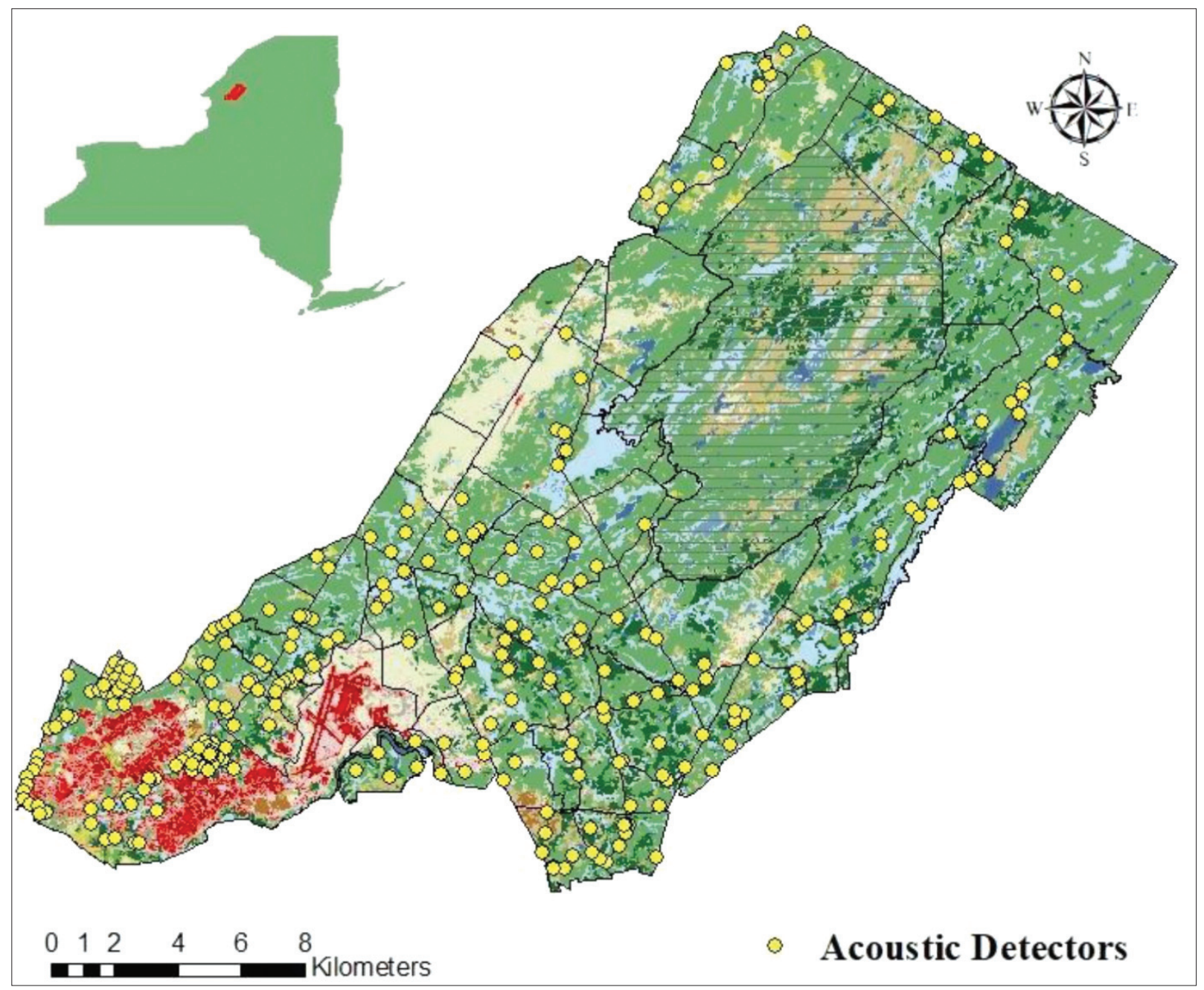

FIG. 1. Acoustic detector locations on Fort Drum, New York, USA during the summer, 2003-2017. Two hundred eighty-nine individual sites were sampled across 15 years within a variety of habitats and patch configurations, with a total of 8,373 detector nights. Hash marks indicate impact zone where no sampling occurred. Inset of New York State on right upper corner, with Fort Drum outlined in red

open water to maximize acoustic recording quality. Following acoustic data acquisition, we visually assessed recorded echolocation passes and scanned in Analook W (Titley Scientific Inc., Columbia MO) to remove extraneous non-bat noise. Cleaned files were then analyzed using Kaleidoscope Pro classifier 4.2.0 (Wildlife Acoustics Inc., Maynard MA), under the recommended settings of the U.S. Fish and Wildlife Service using 0 for the program sensitivity setting, and 3 pulse minimum (U.S. Fish and Wildlife Service, 2017a). However, for these analyses, we did not exclude nights with inclement weather, i.e., precipitation, as would be recommended for M. sodalis surveys for regulatory clearance work (U.S. Fish and Wildlife Service, 2017a).

\section{Predictive Mapping}

Previous research has shown that topographic characteristics (i.e. elevation), land cover variables (i.e. canopy cover, habitat, and water bodies), and presence of linear features (i.e. trails and roads) are important determinants of bat activity and occupancy (Humes et al., 1999; Law and Chidel, 2001; Erickson and West, 2003; Brooks and Ford, 2005; Ford et al., 2005; Wolbert et al., 2014). We calculated elevation (m a.s.1.), percent canopy cover, land cover, distance to water $(\mathrm{m})$, and distance to $\mathrm{road} /$ trail (m) to include as variables in our M. lucifugus occupancy and relative activity models for Fort Drum We derived elevation data from U.S. Geological Survey $1 / 3$ arc-second (10 m resolution) digital elevation models (DEM). We estimated elevation for each point by extracting the values of the DEM to our sample locations. We derived percent canopy cover and land cover from the Multi-Resolution Land Characteristics Consortium (MRLC) National Land Cover Database (MRLC, 2017) at $30 \mathrm{~m}$. Because our acoustic locations varied through time, we estimated percent canopy cover for each detector and for each year by extracting the values of the most recent canopy cover layer respective to the sample year from the MRLC at 2003,2006 , and 2011 , or by substituting those in later years where canopy cover was physically recorded at the site. Additional land cover data was also obtained from Fort Drum to improve the accuracy of our derived MRLC layer. We used Spatial Analyst Toolbox to reclassify our Fort Drum land cover data into five general categories (forest, shrub land, wetland, development, and barren). We acquired wetland data from the 
TABLE 1. Acoustic sampling intensity and variation by year across Fort Drum, New York, during the summer, 2003-2017, with minimum and maximum number of nights, mean number of nights, and total number of sites sampled for each year

\begin{tabular}{rrrrr}
\hline \multirow{2}{*}{ Year } & \multicolumn{2}{c}{ Number of detector nights/site } & \multirow{2}{*}{ Number of sites } \\
\cline { 2 - 4 } & Minimum & Maximum & Mean & \\
\hline 2017 & 64 & 83 & 77.8 & 5 \\
2016 & 8 & 28 & 15.0 & 81 \\
2015 & 2 & 118 & 11.0 & 129 \\
2014 & 81 & 131 & 103.6 & 5 \\
2013 & 2 & 187 & 29.6 & 49 \\
2012 & 1 & 223 & 38.9 & 55 \\
2011 & 1 & 128 & 17.8 & 57 \\
2010 & 1 & 6 & 2.6 & 19 \\
2009 & 2 & 2 & 2.0 & 13 \\
2008 & 1 & 2 & 1.8 & 12 \\
2007 & 2 & 2 & 2.0 & 15 \\
2006 & 2 & 2 & 2.0 & 18 \\
2005 & 1 & 2 & 1.8 & 21 \\
2004 & 1 & 3 & 1.9 & 17 \\
2003 & 1 & 1 & 1.0 & 5 \\
\hline
\end{tabular}

National Wetlands Inventory (U.S. Fish and Wildlife Service, 2017b) along with road/ trail layers from Fort Drum Military Installation. We then used the Euclidean Distance in Spatial Analyst Toolbox in ArcGIS 10.5 (ESRI, Inc., Redlands, CA), in conjunction with derived land cover road/trail, and NWI to calculate and assign variable distances to survey sites. We used the observed cell values for each raster layer at Fort Drum to predict relative bat activity levels. We used Program R (ver. 3.5.1 $\mathrm{R}$ Core Team, 2018) to rearrange the individual raster layers into vectors and conversely centered and scaled each value with respect to the mean and standard deviation of our sampled covariates. We combined the associated vectors into a data frame and used the predict function in $\mathrm{R}$ to predict our global relative activity model onto the new data frame, encompassing all of Fort Drum, for each year. Due to differences in resolution between layers, we used ArcGIS 10.5 to visualize the predicted relative activity for each year across Fort Drum at $30 \mathrm{~m}$ resolution, as all other layers could be scaled to this resolution.

\section{Activity Analysis}

To assess $M$. lucifugus activity relative to environmental characteristics on Fort Drum, we fit a generalized linear mixed model (GLMM) package glmmADMB in program R (Bolker et al., 2012; R Core Team, 2018) using a negative binomial distribution on our data from 2003-2017 (Fournier et al., 2012). We used site as a random effect to account for repeated samples at individual sites, and included percent canopy cover, elevation, distance to road/trail, distance to water, land cover (both at a fine scale, 12 land cover types using NLCD (mixed forest, evergreen forest, deciduous forest, open water, emergent wetland vegetation, woody wetland, scrub/shrub, grass, barren rock, cultivated crop, pasture/hay, and developed) and broad scale (our reclassified land cover types from the Fort Drum land cover dataset)), day, and year as fixed effects (Tables 2 and 3). We included year and date to explain variations in relative activity across time. This allowed for predicting relative activity across Fort Drum for each year. We fit a set of a priori models representing individual hypotheses about activity patterns relative to our four objectives (Tables 2 and 3). We centered and scaled all continuous covariates to aid in model fitting and interpretation. Notably, this puts all continuous variables on the same scale, thereby permitting direct comparisons of effect sizes (Schielzeth, 2010). To assess potential curvilinear effects of certain variables and explore nonlinear relationships between our environmental variables and bat activity, we assessed post hoc models that fit 2 nd order polynomials on continuous variables (Royston and Altman, 1994). We then compared models using Akaike's Information Criterion Corrected for small sample size (AICc) (Burnham and Anderson, 2002, 2004).

\section{Accounting for Spatial Autocorrelation}

We assessed spatial autocorrelation among acoustic detector sites using Moran's I and neighborhood matrices (Dray et al., 2006). Our goal was to ensure that we could predict M. lucifugus relative activity across the landscape using our global model between sampled sites. In addition, we used spatial correlograms in package pgirmess (ver. 1.6.9) in R (Giraudoux et al., 2017) to assess autocorrelation in M. lucifugus relative activity per site night. We then used the same method to assess our fitted models' residuals to demonstrate how spatial autocorrelation is

TABLE 2. Variables included in candidate models describing bat activity and occupancy with justification and supporting literature for each parameter. Candidate models represented bat activity on Fort Drum during the summer, 2003-2017

\begin{tabular}{|c|c|c|}
\hline Parameter & Justification & Supporting literature \\
\hline Date & Bat activity varies in intensity and spatially by date & O'Shea et al., 2003; Perry et al., 2010; Ford et al., 2011 \\
\hline Year & $\begin{array}{l}\text { WNS affect bats have lower activity post-WNS } \\
\text { than pre-WNS }\end{array}$ & $\begin{array}{l}\text { Frick et al., 2010; Ford et al., 2011; Coleman and Reichard, } \\
2014\end{array}$ \\
\hline $\begin{array}{l}\text { Percent } \\
\text { canopy cover }\end{array}$ & Bats may be attracted to openings within canopy & Humes et al., 1999; Erickson and West, 2003 \\
\hline Elevation & Bat activity varies along an elevation gradient & Wolbert et al., 2014 \\
\hline $\begin{array}{l}\text { Distance to } \\
\mathrm{road} / \text { trail }\end{array}$ & $\begin{array}{l}\text { Bats use linear features such as roads and trails as } \\
\text { foraging habitat }\end{array}$ & $\begin{array}{l}\text { Law and Chidel, 2001; Menzel et al., 2002; Caras and Korine, } \\
\text { 2009; Hein et al., 2009 }\end{array}$ \\
\hline $\begin{array}{l}\text { Distance to } \\
\text { water }\end{array}$ & Bats utilize water bodies as drinking sources & $\begin{array}{l}\text { Brooks and Ford, 2005; Ford et al., 2005; Adams and } \\
\text { Thibault, 2006; Loeb and O'Keefe, } 2006\end{array}$ \\
\hline Habitat & $\begin{array}{l}\text { Bats select preferential habitats associated with } \\
\text { foraging and morphology }\end{array}$ & $\begin{array}{l}\text { Jung et al., 1999; Brooks and Ford, 2005; Loeb and O'Keefe, } \\
\text { 2006; Schirmacher et al., } 2007\end{array}$ \\
\hline
\end{tabular}


TABLE 3. Variables included in candidate models representing bat activity and occupancy on Fort Drum during the summer, 2003-2017. Variables were used in different combinations, and highly correlated variables were not included within a single candidate model

\begin{tabular}{ll}
\hline \multicolumn{1}{c}{ Variable name } & \multicolumn{1}{c}{ Variable Explanation } \\
\hline Date & Day of year \\
Year & Years expanding our study (2003-2017) \\
Canopy cover & Percent canopy cover \\
Elevation & Elevation gradient across Fort Drum \\
Distance to road/trail & Distance of sampling point from road/trail \\
Distance to water & How far sampling point is from a water source \\
Habitat-Fine scale & Included all landcover types associated with NLCD \\
Habitat-Broad scale & Included general habitats: forest, wetlands, shrub, open water, development, and barren \\
\hline
\end{tabular}

addressed and reduced through the use of our GLMM (Dormann et al., 2007). We then used package vegan (ver. 2.5-5) in $\mathrm{R}$ (Oksanen et al., 2018) to fit a redundancy analysis using the function varplot to assess the total variation explained by our significant positive spatial vectors.

\section{Occupancy Analysis}

Under USFWS M. sodalis survey guidelines, acceptance of presence of $M$. sodalis must have a maximum likelihood estimate (MLE), the probability that a species is misclassified as present when in fact it is absent, $\alpha \leq 0.05$ threshold (U.S. Fish and Wildlife Service, 2017a). Accordingly, we applied this same filter to $M$. lucifugus and grouped automated identification nightly MLE values into two categories for each individual year. We considered MLE values $\leq 0.05$ to indicate species nightly presence, values above that were considered to indicate absence. We then used the resulting binary data as species detection histories for each site to model occupancy for M. lucifugus (MacKenzie et al., 2002). We created a set of occupancy models representing a priori hypotheses in program PRESENCE, Version 12.10 (U.S. Geological Survey, Patuxent, MD) to estimate probabilities of occupancy $(\Psi)$ and detection $(\rho)$ for $M$. lucifugus from 2003-2017. Due to limited sampling effort (maximum nightly sample being two nights) for years prior to WNS (2003-2007), we combined this data together representing preWNS, under the assumption that site wide occupancy did not change across pre-WNS years. For each year, we fit all possible subsets incorporating the same covariates used in our relative activity models, including: percent canopy cover, elevation, distance to road/trail, distance to water, and land cover (both at fine and broad scale) as covariates that may affect probabilities of occupancy and detection. We used AICc to rank models and compare weights of evidence among models in the candidate set (Burnham and Anderson, 2002, 2004).

\section{RESULTS}

From 2003 to 2017, we sampled 8,373 total detector nights, encompassing 289 individual sites across Fort Drum (Fig. 1). Over the entire study duration, this accounted for $1,022,188$ individual files, of which 472,849 were identified by the software as bat passes from the nine bat species, including M. lucifugus ( $n=76,916$ passes). We found 80 significantly positive eigenvectors associated with site locations. Spatial eigenvectors only explained $0.07 \%$ of the variation in M. lucifugus activity. The best-approximating model included date, percent canopy cover, land cover (on a broad scale level), distance to road/trail, and year, with only three other models within four $\triangle \mathrm{AIC}$ units (Table 4). In all models, date, canopy cover, and distance to road/trail appeared to significantly affect relative activity of $M$. lucifugus $(P \leq 0.05)$, where $M$. lucifugus activity was negatively correlated with each (Table 5). Only wetland habitat (including emergent and woody wetlands) was significantly different from zero having a positive effect on $M$. lucifugus activity $(P \leq 0.05)$ (Table 5). Additionally, the years' postWNS (2010-2017) were significantly different from zero, with a negative relationship with $M$. lucifugus activity (Table 5). This overall negative trend through the years is illustrated by the M. lucifugus predicted relative activity maps prior to WNS, 2004-2007, during the initial WNS onset, 2008-2009, full WNS impact, 2010-2015 and post-WNS localized stability (Fig. 2) and the fitted regression line on the mean echolocation passes for each year (Fig. 3).

Myotis lucifugus presence was denoted during at least 1 sampling event, at any site, for all years examined. Of our predictive models tested, the best supported model varied by year, however, the model where occupancy estimates were constant with regard to environmental factors $[\Psi()$.$] was either com-$ peting (models within two $\triangle$ AIC units) or was the best supported model (Table 6). The exception was 2013 where the best supported model included habitat as an important predictor of occurrence (Table 6). Beyond these, other tested models that included variables such as elevation, percent canopy cover, distance to water, distance to road/trail, and habitat had little empirical support for estimating occupancy, but were predictors for describing detection (Table 6). Occupancy estimates varied for our best supported 
TABLE 4. Rankings of models predicting M. lucifugus activity at Fort Drum during the summer 2003-2017, with $k$ (number of parameters), Akaike's information criteria (AIC) value, Akaike's information criteria Corrected (AIC $\mathrm{c}_{\mathrm{c}}$ ) value corrected for small sample size, difference in $\mathrm{AIC}_{\mathrm{c}}$ value between best supported model and $\mathrm{i}^{\text {th }}$ model $\left(\triangle \mathrm{AIC}_{\mathrm{c}}\right), w_{\mathrm{i}}\left(\right.$ model weight), and $\mathrm{ER}_{\mathrm{i}}(\mathrm{evidence}$ ratio)

\begin{tabular}{|c|c|c|c|c|c|c|}
\hline Model & $k$ & AIC & $\mathrm{AIC}_{\mathrm{c}}$ & $\Delta \mathrm{AIC}_{\mathrm{c}}$ & $w_{\mathrm{i}}$ & $\mathrm{ER}_{\mathrm{i}}$ \\
\hline $\begin{array}{l}\text { Day + Day }{ }^{2}+\text { Canopy cover + Canopy cover }{ }^{2}+\text { Habitat_broadscale } \\
+ \text { Distance to road } / \text { trail }+ \text { Distance to } \text { road } / \text { trail }^{2}+\text { Year }\end{array}$ & 25 & 32502.4 & 32502.6 & 0 & 0.44 & 1.00 \\
\hline $\begin{array}{l}\text { Day }+ \text { Day }^{2}+\text { Canopy cover }+ \text { Canopy cover }{ }^{2}+\text { Distance to road } / \text { trail } \\
+ \text { Distance to road } / \text { trail }{ }^{2}+\text { Year }\end{array}$ & 21 & 32503.2 & 32503.3 & 0.75 & 0.30 & 1.45 \\
\hline $\begin{array}{l}\text { Day }+ \text { Day }^{2}+\text { Canopy cover }+ \text { Canopy cover }{ }^{2}+\text { Habitat_broadscale } \\
+ \text { Distance to road } / \text { trail }+ \text { Distance to road } / \text { trail }^{2}+\text { Distance to water } \\
+ \text { Distance to water }{ }^{2}+\text { Year }\end{array}$ & 27 & 32504.0 & 32504.2 & 1.63 & 0.20 & 2.26 \\
\hline $\begin{array}{l}\text { Day }+ \text { Day }^{2}+\text { Canopy cover }+ \text { Canopy cover }{ }^{2}+\text { Elevation }+ \text { Elevation }^{2} \\
+ \text { Habitat_broadscale }+ \text { Distance to road/trail }+ \text { Distance to road } / \text { trail }^{2} \\
+ \text { Distance to water }+ \text { Distance to } \text { water }^{2}+\text { Year }\end{array}$ & 29 & 32506.4 & 32506.6 & 4.06 & 0.06 & 7.60 \\
\hline
\end{tabular}

model in each year (Table 7). Years with small number of sampling sites (five sites for 2014 and 2017) had derived occupancy estimates but confidence intervals that ranged from 0 to 1 . Conversely, years with large numbers of sampling sites (129 sites for 2015) had occupancy estimates much lower than other years $(0.265$ versus 0.505 , the next lowest metric). For 2011 and 2013, where fine scale habitat metrics were in our best supported model,

TABLE 5. Parameter estimates of best supported model predicting $M$. lucifugus activity at Fort Drum during the summer, 2003-2017

\begin{tabular}{lrrrr}
\hline \multicolumn{1}{c}{ Parameter } & Estimate & $\mathrm{SE}$ & \multicolumn{1}{c}{$\mathrm{z}$} & $P(>|\mathrm{z}|)$ \\
\hline Wetlands & 3.63 & 1.17 & 3.11 & 0.002 \\
Date & 0.03 & 0.03 & 1.08 & 0.282 \\
Date $^{2, \text { a }}$ & -0.66 & 0.02 & -29.78 & $<0.001$ \\
Canopy cover $_{\text {Canopy cover }}$, a & -0.69 & 0.20 & -3.49 & $<0.001$ \\
Developed & -0.61 & 0.19 & -3.14 & 0.002 \\
Forest & -1.84 & 1.00 & -1.84 & 0.065 \\
Shrub & -1.29 & 0.81 & -1.59 & 0.112 \\
Open Water & -1.20 & 0.86 & -1.39 & 0.163 \\
Distance to road/trail & -0.46 & 0.82 & -0.56 & 0.577 \\
Distance to road/trail ${ }^{2,}$ a & -0.46 & 0.15 & -2.98 & 0.003 \\
Year2004 & 0.06 & 0.02 & 2.61 & 0.009 \\
Year2005 & 2.40 & 0.89 & 2.70 & 0.007 \\
Year2006 & 1.00 & 0.88 & 1.14 & 0.254 \\
Year2007 & 0.85 & 0.89 & 0.95 & 0.341 \\
Year2008 & 1.57 & 0.91 & 1.73 & 0.084 \\
Year2009 & 0.10 & 0.91 & 0.11 & 0.912 \\
Year2010 & 0.56 & 0.84 & 0.67 & 0.505 \\
Year2011 & -1.97 & 0.88 & -2.23 & 0.026 \\
Year2012 & -2.13 & 0.86 & -2.48 & 0.013 \\
Year2013 & -2.63 & 0.86 & -3.07 & 0.002 \\
Year2014 & -2.43 & 0.86 & -2.83 & 0.005 \\
Year2015 & -2.07 & 0.86 & -2.41 & 0.016 \\
Year2016 & -2.20 & 0.86 & -2.55 & 0.011 \\
Year2017 & -1.53 & 0.85 & -1.79 & 0.073 \\
\hline & -1.86 & 0.86 & -2.16 & 0.031 \\
\hline
\end{tabular}

a - Quadratic term occupancy estimates per habitat varied 0.678 to 0.837 for 2011 and 0.571 to 0.774 for 2013 (Table 8).

\section{DiSCUSSION}

Irrespective of known habitat associations and correlates for $M$. lucifugus, our findings corroborate results by (Brooks, 2011; Dzal et al., 2011; Ford et al., 2011; Ingersoll et al., 2016) that relative M. lucifugus activity has significantly decreased in years following WNS. Prior to WNS, M. lucifugus was one of the most abundant and common species of bats in North America, with seasonal increases in activity and abundance consistent with spring arrival from hibernation areas and juvenile volancy in mid-summer (Frick et al., 2010; Ford et al., 2011). Collapse of such a prominent species in a short time period, $>90 \%$ in a single year (Blehert et al., 2009; Frick et al., 2010), has had both inter and intraspecific consequences for the bat community at Fort Drum and presumably elsewhere in the Northeast (Jachowski et al., 2014a). As the effects of WNS on bats continue to cause declines in the distribution and abundance of affected bat species (Frick et al., 2010; Langwig et al., 2012), there is an increased need to employ acoustic sampling in addition to (or in place of) mist-netting to adequately describe changes in both relative activity and occupancy. $M$. lucifugus is a good model species intrinsic to understanding the relationship between disease dynamics, species susceptibility, and environmental conditions. Fort Drum can be used as a model to identify suitable environmental characteristics important for $M$. lucifugus, to understand disease dynamics as it relates to local and regional population declines, and to synthesize these declines into relative activity and occupancy modeling. 


\section{Relative Activity}

The use of models incorporating relative activity to describe changes in bat communities is widely used (Law and Chidel, 2001; Brooks and Ford, 2005; Brooks, 2011; Dzal et al., 2011; Ford et al., 2011; Ingersoll et al., 2016). For our models of M. lucifugus relative activity, date (which indirectly incorporates weather influences), percent canopy cover, and distance to road/trail were all significantly different from zero and were negatively correlated with $M$. lucifugus activity. Further, it is important to note that the inclusion of nights with inclement weather and during full moon periods in the later years (2012-2017) in conjunction with WNS, could have caused further negative bias in recording echolocation passes. Ford et al. (2011) showed that as summer progresses in a post-WNS setting, M. lucifugus activity decreased, suggesting limited recruitment. However, our reexamination of presumed volancy dates for juveniles may suggest the temporal decrease reported in Ford et al. (2011) may have overestimated the extent of decreased reproduction and recruitment (Nocera et al., 2019). Our sample variation in site placement in regards to distance to $\mathrm{road} /$ trail and percent canopy cover, i.e., low to high clutter, allowed us to better assess activity changes relative to these habitat features. Canopy cover and distance to road/trail had significant negative effects on $M$. lucifugus relative activity. This is consistent with research indicating decreasing rates of bat activity and detection power as canopy cover increases, and increased distance of sampling sites from more open corridors as this species is adapted


FIG. 2. Predicted relative activity for M. lucifugus across Fort Drum during the summer, 2004-2007: A - prior to white-nose syndrome onset, 2008-2009; B - with the initial onset of white-nose syndrome, 2010-2015; C — following full impact of whitenose syndrome, and, 2016-2017; D — as bats display localized stability following white-nose syndrome. Relative activity modeled from mean echolocation passes per night per site. Hash marks indicate impact zone where no sampling occurred. Mean relative activity $+\mathrm{SE}$ across all raster cells was calculated for the entire installation 


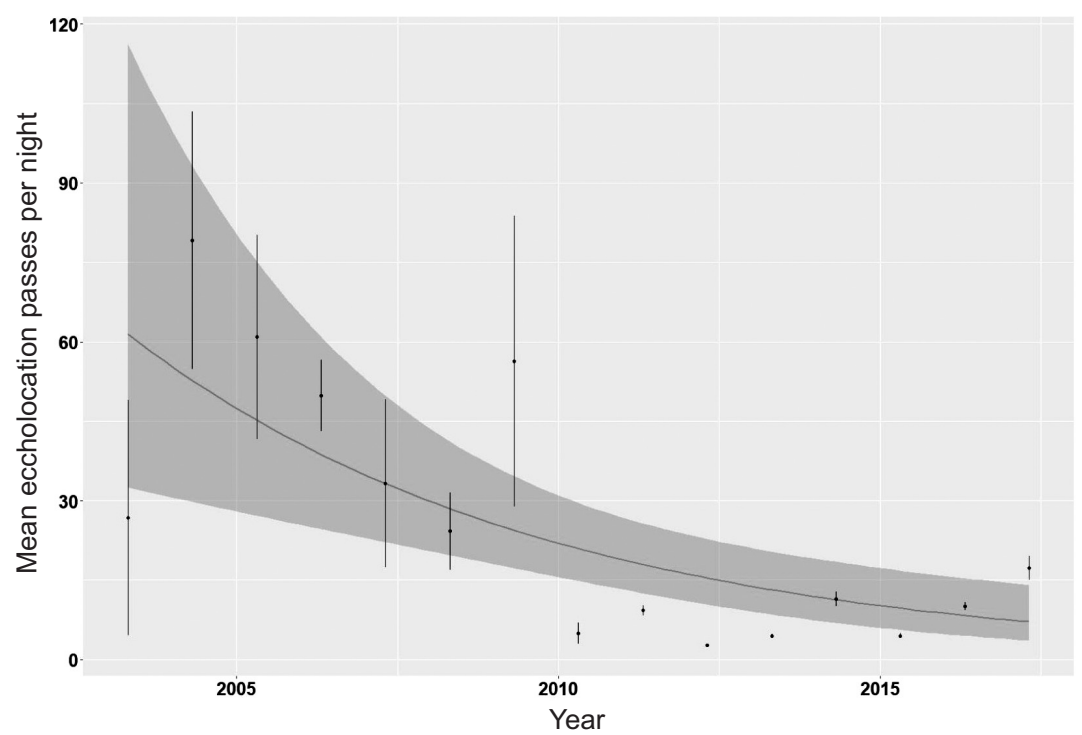

FIG. 3. Long-term acoustical monitoring trends for M. lucifugus during the summers, 2003-2017 at Fort Drum. Mean echolocation passes with Standard Error for each year are indicated by points. White-nose syndrome impacts began locally in 2008 . The fitted regression line from our best-supported model indicates trend in activity with $95 \%$ confidence interval

to foraging in low-clutter environments (Sherwin et al., 2000; Law and Chidel, 2001; Menzel et al., 2002; Weller and Zabel, 2002, Coleman et al.,

TABLE 6. Rankings of models predicting M. lucifugus occupancy at Fort Drum during the summer, 2003-2017. With model parameters for both occupancy $(p s i()$.$) and detection$ $(\mathrm{p}()$.$) , Akaike's information criteria Corrected \left(\mathrm{AIC}_{\mathrm{c}}\right)$ value, difference in AIC value between best supported model and $\mathrm{i}$-th model $(\triangle \mathrm{AIC})$, and wi (model weight). Model abbreviations are as follows: $\mathrm{CC}=$ Canopy cover, DRT $=$ Distance to road/trail, and $\mathrm{EV}=$ Elevation

\begin{tabular}{llccc}
\hline \multicolumn{1}{c}{ Year } & \multicolumn{1}{c}{ Model } & $\mathrm{AIC}_{\mathrm{c}}$ & $\Delta \mathrm{AIC}_{\mathrm{c}}$ & $w_{\mathrm{i}}$ \\
\hline Pre-WNS & psi(.),p(.) & 125.63 & 0 & 0.75 \\
2008 & psi(.),p(.) & 33.07 & 0 & 0.73 \\
& psi(Habitat),p(DRT,CC) & 35.03 & 1.96 & 0.27 \\
2009 & psi(.),p(DRT,CC) & 32.4 & 0 & 0.36 \\
& psi(Habitat),p(DRT,CC) & 32.4 & 0 & 0.36 \\
& psi(.),p(.) & 34.28 & 1.88 & 0.14 \\
& psi(Habitat),p(.) & 34.29 & 1.89 & 0.14 \\
2010 & psi(.),p(DRT,CC) & 55.42 & 0 & 0.37 \\
& psi(Habitat),p(DRT,CC) & 56.31 & 0.89 & 0.23 \\
& psi(.),p(DRT,CC,EV) & 56.73 & 1.31 & 0.19 \\
& psi(Habitat),p(DRT,CC,EV) & 57.7 & 2.28 & 0.12 \\
2011 & psi(Habitat),p(DRT,CC) & 1095.65 & 0 & 0.58 \\
& psi(.),p(DRT,CC) & 1096.32 & 0.67 & 0.42 \\
2012 & psi(.),p(.) & 1777.66 & 0 & 0.53 \\
& psi(Habitat),p(.) & 1779.17 & 1.51 & 0.25 \\
& psi(Habitat),p(DRT,CC) & 1780.05 & 2.39 & 0.16 \\
2013 & psi(Habitat),p(DRT,CC) & 1243.12 & 0 & 0.99 \\
2014 & psi(.),p(.) & 684.89 & 0 & 0.99 \\
2015 & psi(.),p(DRT,CC) & 1729.32 & 0 & 0.91 \\
2016 & psi(.),p(DRT,Habitat,CC) & 1417.32 & 0 & 0.68 \\
2017 & psi(.),p(CC,DRT) & 344.38 & 0 & 0.69 \\
& psi(h),p(CC,DRT) & 345.98 & 1.60 & 0.31 \\
\hline & & & & \\
& & & &
\end{tabular}

2014b). Furthermore, our analysis showed M. lucifugus activity was greatest in wetland areas, as did other studies (Zimmerman and Glanz, 2000; Ford et al., 2005; Menzel et al., 2005). Nonetheless, our expansive inclusion of road/trail conditions as one variable type and the close proximity of many wetland survey sites limits somewhat our inference regarding $M$. lucifugus response in other areas of the Northeast where roads are associated with more urbanized environments, experience greater vehicular traffic, or occur in primarily upland conditions.

Through our geospatial analysis of $M$. lucifugus activity, we observed a time lag when $M$. lucifugus began to show significant changes in relative activity due to WNS. Though the disease was first documented at Fort Drum in 2008 (Dobony et al., 2011), our analysis suggests that activity did not greatly decrease until 2010. An artifact of the communicability and spread of WNS on the landscape, where, as this disease spreads among individuals over time and across the region fewer areas offer less protection (Wilder et al., 2011). Unfortunately, our temporal and spatial analysis point to no clear signs of wide scale recovery across the entire landscape, as measured through the surrogate of relative activity, over the 10 years that WNS has affected bats at Fort Drum. Since the first documented case of WNS, regional population declines in the Northeast are estimated to be $>90 \%$ (Blehert et al., 2009; Frick et al., 2010; Dzal et al., 2011). Still, resiliency to long-term WNS exposure has been observed in some remaining M. lucifugus locally, whereby some 
TABLE 7. Occupancy estimates from yearly top models predicting $M$. lucifugus occupancy at Fort Drum during the summer, 2003-2017. With model parameters for both occupancy (psi(.)) and detection $(\mathrm{p}()),$.$N sites sampled within that given year,$ $\psi$ (measure of occupancy), SE (standard error), and 95\% CI (confidence interval). Model abbreviations are as follows: CC $=$ Canopy cover, DRT $=$ Distance to $\mathrm{road} /$ trail, and $\mathrm{EV}=$ Elevation

\begin{tabular}{llcccc}
\hline \multicolumn{1}{c}{ Year } & \multicolumn{1}{c}{ Model } & $N$ & $\psi$ & SE & $95 \%$ CI \\
\hline Pre-WNS, 2003-2007 & psi(.),p(.) & 87 & 0.86 & 0.04 & $0.75-0.93$ \\
2008 & psi(.),p(.) & 12 & 0.84 & 0.13 & $0.43-0.97$ \\
2009 & psi(.),p(DRT,CC) & 13 & 1.00 & 0.00 & $0.00-1.00$ \\
2010 & psi(.),p(DRT,CC) & 19 & 0.79 & 0.14 & $0.43-0.95$ \\
2011 & psi(Habitat),p(DRT,CC) & 57 & 0.51 & 0.50 & $0.36-0.65$ \\
2012 & psi(.),p(.) & 55 & 0.65 & 0.08 & $0.49-0.78$ \\
2013 & psi(Habitat),p(DRT,CC) & 49 & 0.50 & 0.50 & $0.36-0.64$ \\
2014 & psi(.),p(.) & 5 & 1.00 & 0.00 & $0.00-1.00$ \\
2015 & psi(.),p(DRT,CC) & 129 & 0.26 & 0.04 & $0.19-0.35$ \\
2016 & psi(.),p(DRT,Habitat,CC) & 81 & 0.79 & 0.05 & $0.69-0.87$ \\
2017 & psi(.),p(CC,DRT) & 5 & 0.80 & 0.18 & $0.31-0.97$ \\
\hline
\end{tabular}

individuals continue to show relatively high reproductive effort (Dobony et al., 2011; Frick et al., 2017; Langwig et al., 2017; Dobony and Johnson, 2018). Whether good biological performance for small segments of populations is meaningful for the wider landscape in the near-term is unknown. Still, from 2010 onwards, mean relative activity did increase at Fort Drum, though activity is still low relative to pre-WNS years (Fig. 2). Our work shows that a stabilization of $M$. lucifugus relative activity may be occurring. If more localized colony increases are realized, hopefully, widespread relative activity increases may become measurable in the Northeast in the future. However, because colonies remain small and activity remains primarily concentrated around maternity sites, any individual

TABLE 8. Occupancy estimates from 2011 and 2013 top models predicting $M$. lucifugus occupancy across habitat types at Fort Drum during the summer, 2003-2017. With habitat condition, $\psi$ (measure of occupancy), SE (Standard Error), and 95\% CI (Confidence Interval)

\begin{tabular}{clccc}
\hline Year & \multicolumn{1}{c}{ Habitat } & $\psi$ & SE & $95 \%$ CI \\
\hline 2011 & Deciduous forest & 0.84 & 0.09 & $0.59-0.95$ \\
& Evergreen forest & 0.68 & 0.06 & $0.54-0.79$ \\
& Mixed forest & 0.68 & 0.06 & $0.54-0.79$ \\
Shrub & 0.68 & 0.06 & $0.54-0.79$ \\
Developed & 0.84 & 0.09 & $0.59-0.95$ \\
Emergent wetland & 0.84 & 0.09 & $0.59-0.95$ \\
& Woody wetlands & 0.84 & 0.09 & $0.59-0.95$ \\
Open water & 0.68 & 0.06 & $0.54-0.79$ \\
Deciduous forest & 0.64 & 0.07 & $0.49-0.76$ \\
Evergreen forest & 0.57 & 0.04 & $0.49-0.64$ \\
Mixed forest & 0.64 & 0.07 & $0.49-0.77$ \\
& Shrub & 0.64 & 0.07 & $0.49-0.76$ \\
& Developed & 0.64 & 0.07 & $0.49-0.76$ \\
& Emergent wetland & 0.64 & 0.07 & $0.49-0.76$ \\
Woody wetlands & 0.77 & 0.11 & $0.49-0.93$ \\
Open water & 0.64 & 0.07 & $0.49-0.76$ \\
\hline
\end{tabular}

colony's spatial distribution may not encompass sampling locations across broader landscapes. Therefore, positive changes in relative activity may be difficult to document on the wider landscape. Additionally, M. lucifugus on Fort Drum may be associated with multiple hibernation sites where there could be wide variability in survivorship in these wintering populations. Therefore, additional time may be needed to fully understand accurate population level changes expressed on this summer landscape. It is plausible, given our results, that there is either a continuing population loss but not at the absolute scale when WNS first started to affect $M$. lucifugus regionally (Frick et al., 2017; Langwig et al., 2017) or stable population, in which increases are beyond our power to detect broadly. It is important to note however, that limitations in our sampling design including variation in sampling effort and number of sampling sites between years, did affect our ability to predict activity across Fort Drum temporally over the years surveyed. Although we can accurately predict relative activity across Fort Drum by combining all sites and years into a single model, the variability from the spatial illustrations of M. lucifugus at Fort Drum, specifically with preWNS years, is in part a sampling artifact causative of yearly differences in sampling effort and size (Figs. 2 and 3). Furthermore, minimal sampling was done in the western portion of Fort Drum and no sampling was done in the Impact Area. Though it is likely that bats utilize these areas, relative activity predictions into these areas should be viewed cautiously.

\section{Occupancy}

Across the landscape scale of Fort Drum, occupancy metrics suggest relatively high probability of 
occurrence across sampled sites regardless of year. Additionally, our yearly occupancy models suggest few of the chosen covariates are important predictors for occupancy. There are four probable reasons to why none of the included covariates effected $M$. lucifugus occupancy. First, the variables we measured might not be highly important factors in predicting occupancy for bats on Fort Drum. Potential unmeasured variables (i.e. fine scale landscape features) in this analysis might be important predictors for occupancy. Second, the binary response (either present or absent) groupings in occupancy are an oversimplification of what is occurring on the landscape. Third, the spatial extent of Fort Drum, and the degree to which our sites are spatially autocorrelated, may limit the ability to address the importance of environmental variables on occupancy as bats are highly vagile (Steenweg et al., 2018). Lastly, the sampling effort and size, influences occupancy estimates. As such, understanding the underlying limitations of occupancy metrics with regards to changing abundances, spatial scale, and autocorrelation is critical for researchers and managers looking to effectively and efficiently monitor for threatened and endangered species (MacKenzie et al., 2002). In our analysis, occupancy estimates were influenced by the balance of sampling effort and sample size. First, due to low sampling effort (maximum two nights) and few sites surveyed each individual year pre-WNS, we could not develop robust occupancy models for each individual year from 2003-2007. Therefore, we had to combine these years to be able to develop an accurate model to determine $M$. lucifugus presence for pre-WNS. Second, for 2014 and 2017, we had a large number of sampling nights but few allocated sites (five sites). Although we were able to generate estimates for detection and occupancy, our model lacked the ability to draw strong inference across Fort Drum. Finally, for 2015 sampling at Fort Drum was specifically targeted for M. septentrionalis, and therefore sites were positioned in areas less suitable for M. lucifugus, with surveys occurring in areas with a larger proportion of upland forests rather than in wetlands and more open corridors. Accordingly, our analysis for 2015 had a lower occupancy estimate than any other year that was both accurate and precise in terms of estimating occupancy across Fort Drum. However, this is caveated by the fact that increased sampling effort may have allowed for sites to record presence if the survey duration had been longer that year at these sites.

\section{Relative Activity versus Occupancy}

The patterns associated with occupancy and population dynamics, such as abundance, relative activity, and distribution of a species are affected by different spatial and temporal scales (Hecnar and M'Closkey, 1997; Donovan and Flather, 2002; Steenweg et al., 2018). Specifically, research on amphibians, reptiles, and birds has shown these relationships relative to environmental conditions (Wiens et al., 1987; Hecnar and M'Closkey, 1997; Hurlbert and Jetz, 2007; Steenweg et al., 2018). Although there are clear examples of how decreasing abundance does not indicate a negative trend in occupancy (Hecnar and M'Closkey, 1997; Blackburn et al., 1998; Boeken and Shachak, 1998; Donald and Fuller, 1998; Gaston and Curnutt, 1998; Gaston et al., 2000; Latham et al., 2014), the premise that wildlife populations occupy the same locations both prior to and following a reduction in size has garnered little attention in the literature, especially in bats. The vagility of a species and associated habitat constraints does influence the relationships between occurrence and abundance (Gaston and Curnutt, 1998; Gaston et al., 2000; Frick et al., 2008). For example, species that are restricted to a suite of local environmental conditions and with low or short dispersal rates, such as herpetofauna, a change in abundance will often have strong correlations with occupancy. Species that are highly mobile or have minimal habitat constraints, such as avifauna and bats, the relationship between occupancy and changing abundances may not be clear (Gaston and Curnutt, 1998). Being highly mobile, bats tend to have large home range sizes (Owen et al., 2003; Kniowski and Gehrt, 2014; Maxell, 2015; Nelson and Gillam, 2016). At Fort Drum, M. lucifugus have core mean home ranges $>140$ ha (Coleman et al., $2014 c$ ). Based on the foraging and home range characteristics of $M$. lucifugus, a reduction in overall abundance could have no effect on occupancy as even a reduced population still, in theory, could be present anywhere at Fort Drum over the summer season.

Nonetheless, our analysis of $M$. lucifugus illustrate this dichotomy in the occupancy-abundance relationship. We saw minimal change in occupancy through time for M. lucifugus. Similarly, none of our environmental variables seemed to impact occupancy, and when they did, these differences were not significant. This might be attributed to the fact that occupancy analysis requires more site-level and landscape variability as well as more instances of 
complete absences than encountered at Fort Drum. Conversely, our relative activity models not only identified important topographic and land cover variables important to M. lucifugus relative activity, but had the predictive power to document changes in relative activity induced by WNS across Fort Drum over 15 years. When compared to occupancy, relative activity reflected both the change in activity we predicted and the contraction of populations resulting from WNS; whereas occupancy modeling, with the oversimplification of data as simply present or absent, represented a loss of resolution even at the large landscape scale of Fort Drum. However, realizing that there is an $80 \%$ chance of $M$. lucifugus occupancy at any site at Fort Drum may still be informative. Regardless, continued acoustic monitoring of bat species, such as M. lucifugus in the Northeast to assess ongoing temporal, spatial, and habitat association changes, and as a guide to efficiently direct mist-netting should rely more on relative activity as the metric of choice rather than occupancy estimates.

\section{ACKNOWLEDGEMENTS}

This work was supported by the U.S Army Corps of Engineers [W9126G-15-2-0005] through the Southern Appalachian Cooperative Ecosystems Study Unit Program. We thank C. Whitman for field assistance. Earlier drafts of this manuscript were reviewed by B. Carstensen. and K. Powers. The use of any trade, product or firm names does not imply endorsement by the U.S. government.

\section{LiterATURE Cited}

Adams, R. A., and K. M. Thibault. 2006. Temporal resource partitioning by bats at water holes. Journal of Zoology (London), 270: 466-472.

Blackburn, T. M., K. J. Gaston, J. J. D. Greenwood, and R. D. GREGORY. 1998. The anatomy of the interspecific abundance-range size relationship for the British avifauna: II. Temporal dynamics. Ecology Letters, 1: 47-55.

Blehert, D. S., A. C. Hicks, M. Behr, C. U. Meteyer, B. M. Berlowski-Zier, E. L. Buckles, J. T. H. Coleman, S. R. DARling, A. GARGAS, R. Niver, et al. 2009. Bat white-nose syndrome: an emerging fungal pathogen? Science, 323: 227-227.

Boeken, B., and M. Shachak. 1998. The dynamics of abundance and incidence of annual plant species during colonization in a desert. Ecography, 21: 63-73.

Bolker, B., H. Skaug, A. Magnusson, and A. Nielson. 2012. Getting started with the glmmADMB package. R package. Available at http://glmmadmb.r-forge.r-project.org/.

Borcard, D., F. Gillet, and P. Legendre. 2011. Numerical ecology with R. Use R!, Springer, New York, 306 pp.

Britzke, E. R., E. H. Gillam, and K. L. Murray. 2013. Current state of understanding of ultrasonic detectors for the study of bat ecology. Acta Theriologica, 58: 109-117.
BrooKs, R. T. 2011. Declines in summer bat activity in central New England 4 years following the initial detection of white-nose syndrome. Biodiversity and Conservation, 20: 2537-2541.

BrooKs, R. T., and W. M. ForD. 2005. Bat activity in a forest landscape of central Massachusetts. Northeastern Naturalist, 12: $447-462$.

Burnham, K. P., and D. R. Anderson. 2002. Model selection and multimodel inference: a practical information-theoretic approach. Springer, New York, NY, 512 pp.

Burnham, K. P., and D. R. ANDERSON. 2004. Multimodel inference understanding AIC and BIC in model selection. Sociological Methods and Research, 33: 261-304.

CARAs, T., and C. Korine. 2009. Effect of vegetation density on the use of trails by bats in a secondary tropical rain forest. Journal of Tropical Ecology, 25: 97-101.

Coleman, J. T. H., and J. D. Reichard. 2014. Bat white-nose syndrome in 2014: a brief assessment seven years after discovery of a virulent fungal pathogen in North America. Outlooks on Pest Management, 25: 374-377.

Coleman, L. S., W. M. Ford, C. A. Dobony, and E. R. Britzke. 2014a. A comparison of passive and active acoustic sampling for a bat community impacted by white-nose syndrome. Journal of Fish and Wildlife Management, 5: 217-226.

Coleman, L. S., W. M. Ford, C. A. Dobony, and E. R. Britzke. $2014 b$. Effect of passive acoustic sampling methodology on detecting bats after declines from white nose syndrome. Journal of Ecology and the Natural Environment, 6: 56-64.

Coleman, L. S., W. M. Ford, C. A. Dobony, and E. R. Britzke. 2014c. Comparison of radio-telemetric home-range analysis and acoustic detection for little brown bat habitat evaluation. Northeastern Naturalist, 21: 431-445.

Cryan, P. M., C. U. Meteyer, J. G. Boyles, and D. S. Blehert. 2010. Wing pathology of white-nose syndrome in bats suggests life-threatening disruption of physiology. BMC Biology, 8: 135.

Diniz-FiLhO, J. A. F., and L. M. BINI. 2005. Modelling geographical patterns in species richness using eigenvectorbased spatial filters. Global Ecology and Biogeography, 14: $177-185$

DoBony, C. A., and J. B. Johnson. 2018. Observed resiliency of little brown myotis to long-term white-nose syndrome exposure. Journal of Fish and Wildlife Management, 8: 168-179.

Dobony, C. A., A. C. Hicks, K. E. Langwig, R. I. Von Linden, J. C. OKoniewski, and R. E. RaInBolt. 2011. Little brown myotis persist despite exposure to white-nose syndrome. Journal of Fish and Wildlife Management, 2: 190-195.

DonALD, P. F., and R. J. FulLER. 1998. Ornithological atlas data: a review of uses and limitations. Bird Study, 45: 129-145.

Donovan, T. M., and C. H. Flather. 2002. Relationships among north american songbird trends, habitat fragmentation, and landscape occupancy. Ecological Applications, 12: $364-374$.

Dormann, C. F., J. M. Mcpherson, M. B. Araújo, R. Bivand, J. Bolliger, G. Carl, R. G. Davies, A. Hirzel, W. Jetz, W. D. KissLing, et al. 2007. Methods to account for spatial autocorrelation in the analysis of species distributional data: a review. Ecography, 30: 609-628.

Dray, S., P. Legendre, and P. R. Peres-Neto. 2006. Spatial modelling: a comprehensive framework for principal coordinate analysis of neighbour matrices (PCNM). Ecological Modelling, 196: 483-493. 
Dzal, Y., L. P. Mcguire, N. Veselka, and M. B. Fenton. 2011. Going, going, gone: the impact of white-nose syndrome on the summer activity of the little brown bat (Myotis lucifugus). Biology Letters, 7: 392-394.

ERICKSON, J. L., and S. D. WEST. 2003. Associations of bats with local structure and landscape features of forested stands in western Oregon and Washington. Biological Conservation, 109: 95-102.

Ford, W. M., M. A. Menzel, J. L. Rodrigue, J. M. Menzel, and J. B. JoHnson. 2005. Relating bat species presence to simple habitat measures in a central Appalachian forest. Biological Conservation, 126: 528-539.

Ford, W. M., J. M. Menzel, M. A. Menzel, J. W. Edwards, and J. C. KILGO. 2006. Presence and absence of bats across habitat scales in the upper Coastal Plain of South Carolina. Journal of Wildlife Management, 70: 1174-1184.

Ford, W. M., E. R. Britzke, C. A. Dobony, J. L. Rodrigue, and J. B. Johnson. 2011. Patterns of acoustical activity of bats prior to and following white-nose syndrome occurrence. Journal of Fish and Wildlife Management, 2: 125-134.

Fournier, D. A., H. J. Skaug, J. Ancheta, J. Ianelli, A. MagNusson, M. N. Maunder, A. Nielsen, and J. Sibert. 2012. AD Model Builder: using automatic differentiation for statistical inference of highly parameterized complex nonlinear models. Optimization Methods and Software, 27: 233-249.

Francl, K. E., W. M. Ford, D. W. Sparks, and V. Brack. 2012. Capture and reproductive trends in summer bat communities in West Virginia: assessing the impact of white-nose syndrome. Journal of Fish and Wildlife Management, 3: $33-42$.

FrANKLIN, J. 2010. Mapping species distributions: spatial inference and prediction. Cambridge University Press, Cambridge, UK, $339 \mathrm{pp}$.

Frick, W. F., J. P. Hayes, and P. A. Heady III. 2008. Patterns of island occupancy in bats: influences of area and isolation on insular incidence of volant mammals. Global Ecology and Biogeography, 17: 622-632.

Frick, W. F., J. F. Pollock, A. C. Hicks, K. E. Langwig, D. S. Reynolds, G. G. Turner, C. M. Butchkoski, and T. H. KunZ. 2010. An emerging disease causes regional population collapse of a common North American bat species. Science, 329: 679-682.

Frick, W. F., T. L. Cheng, K. E. Langwig, J. R. Hoyt, A. F. Janicki, K. L. Parise, J. T. Foster, and A. M. Kilpatrick. 2017. Pathogen dynamics during invasion and establishment of white-nose syndrome explain mechanisms of host persistence. Ecology, 98: 624-631.

Gaston, K. J., and J. L. CurnutT. 1998. The Dynamics of abundance-range size relationships. Oikos, 81: 38-44.

Gaston, K. J., T. M. Blackburn, J. J. D. Greenwood, R. D. Gregory, R. M. Quinn, and J. H. Lawton. 2000. Abundance-occupancy relationships. Journal of Applied Ecology, 37: 39-59.

Giraudoux, P., J. P. Antonietti, C. Beale, D. Pleydell, and M. TREgLiA. 2017. pgirmess: spatial analysis and data mining for field ecologists. R package version 2.5-1. Available at https://CRAN.R-project.org/package=pgirmess.

GonzÁlez-Megías, A., J. M. Gómez, and F. SÁnchez-PiÑero. 2005. Consequences of spatial autocorrelation for the analysis of metapopulation dynamics. Ecology, 86: 3264-3271.

Hecnar, S. J., and R. T. M'Closkey. 1997. Spatial scale and determination of species status of the green frog. Conservation Biology, 11: 670-682.
Hein, C. D., S. B. Castleberry, and K. V. Miller. 2009. Siteoccupancy of bats in relation to forested corridors. Forest Ecology and Management, 257: 1200-1207.

Humes, M. L., J. P. Hayes, and M. W. Collopy. 1999. Bat activity in thinned, unthinned, and old-growth forests in western Oregon. Journal of Wildlife Management, 63: $553-561$.

Hurlbert, A. H., and W. Jetz. 2007. Species richness, hotspots, and the scale dependence of range maps in ecology and conservation. Proceedings of the National Academy of Sciences of the USA, 104: 13384-13389.

Ingersoll, T. E., B. J. SEwALl, and S. K. Amelon. 2016. Effects of white-nose syndrome on regional population patterns of 3 hibernating bat species. Conservation Biology, 30: $1048-1059$.

JABERG, C., and A. GUISAN. 2001. Modelling the distribution of bats in relation to landscape structure in a temperate mountain environment. Journal of Applied Ecology, 38: 1169-1181.

Jachowski, D. S., C. A. Dobony, L. S. Coleman, W. M. Ford, E. R. Britzke, and J. L. Rodrigue. 2014a. Disease and community structure: white-nose syndrome alters spatial and temporal niche partitioning in sympatric bat species. Diversity and Distributions, 20: 1002-1015.

Jachowski, D. S., J. B. Johnson, C. A. Dobony, J. W. Edwards, and W. M. FORD. 2014b. Space use and resource selection by foraging Indiana bats at the northern edge of their distribution. Endangered Species Research, 24: 149-157.

Jung, T. S., I. D. Thompson, R. D. Titman, and A. P. AppleJOHN. 1999. Habitat selection by forest bats in relation to mixed-wood stand types and structure in central Ontario. Journal of Wildlife Management, 63: 1306-1319.

KNIOwsKi, A. B., and S. D. GEHRT. 2014. Home range and habitat selection of the Indiana bat in an agricultural landscape. Journal of Wildlife Management, 78: 503-512.

Langwig, K. E., W. F. Frick, J. T. Bried, A. C. Hicks, T. H. KunZ, and A. M. KilPatrick. 2012. Sociality, densitydependence and microclimates determine the persistence of populations suffering from a novel fungal disease, whitenose syndrome. Ecology Letters, 15: 1050-1057.

Langwig, K. E., J. R. Hoyt, K. L. Parise, W. F. Frick, J. T. Foster, and A. M. KILPATRICK. 2017. Resistance in persisting bat populations after white-nose syndrome invasion. Philosophical Transactions of the Royal Society of Biological Sciences, 372: 20160044.

Latham, M. C., A. D. M. Latham, N. F. Webb, N. A. MCCUTCHEN, and S. Boutin. 2014. Can occupancy-abundance models be used to monitor wolf abundance? PLoS ONE, 9: e102982.

LAw, B. S., and M. ChIDEL. 2001. Bat activity 22 years after first-round intensive logging of alternate coupes near Eden, New South Wales. Australian Forestry, 64: 242-247.

Loeb, S. C., and J. M. O'KeEFe. 2006. Habitat use by forest bats in South Carolina in relation to local, stand, and landscape characteristics. Journal of Wildlife Management, 70: 1210-1218.

MacKenzie, D. I., J. D. Nichols, G. B. Lachman, S. Droege, J. A. Royle, and C. A. Langtimm. 2002. Estimating site occupancy rates when detection probabilities are less than one. Ecology, 83: 2248-2255.

MAXELl, B. A. 2015. Overview of roosting habitat and home range: foraging distance documented for Montana bats. Montana Natural Heritage Program, Helena. Available at 
http://www.biodiversitylibrary.org/bibliography/118587. Accessed April 6, 2018.

Menzel, J. M., M. A. Menzel, J. C. Kilgo, W. M. Ford, J. W. EdWARdS, and G. F. McCRACKEN. 2005. Effect of habitat and foraging height on bat activity in the coastal plain of South Carolina. Journal of Wildlife Management, 69: 235-245.

Menzel, M. A., T. C. Carter, J. M. Menzel, W. M. Ford, and B. R. Chapman. 2002. Effects of group selection silviculture in bottomland hardwoods on the spatial activity patterns of bats. Forest Ecology and Management, 162: 209-218.

Meteyer, C. U., D. Barber, and J. N. Mandl. 2012. Pathology in euthermic bats with white nose syndrome suggests a natural manifestation of immune reconstitution inflammatory syndrome. Virulence, 3: 583-588.

Miller, J. 2010. Species distribution modeling. Geography Compass, 4: 490-509.

MRLC. 2017. Multi-resolution land cover characteristics consortium. Available at https://www.mrlc.gov/. Accessed November 30, 2017.

NALLY, R. M. 2000. Regression and model-building in conservation biology, biogeography and ecology: the distinction between - and reconciliation of — 'predictive' and 'explanatory' models. Biodiversity and Conservation, 9: 655-671.

Nelson, J. J., and E. H. Gillam. 2016. Selection of foraging habitat by female little brown bats (Myotis lucifugus). Journal of Mammalogy, 98: 222-231.

Nocera, T., W. M. Ford, C. A. Dobony, and A. Silvis. 2019. Patterns of acoustical activity of bats prior to and 10 years after WNS on Fort Drum Army Installation, NY. Global Ecology and Conservation, 18: e00633.

Oksanen, J., F. G. Blanchet, M. Friendly, R. Kindt, P. LeGendre, D. Mcglinn, P. R. Minchin, R. B. O'Hara, G. L. SimPSON, P. Solymos, et al. 2018. Vegan: community ecology package. R package version 2.5-1. Available at https:// CRAN.R-project.org/package= $=$ vegan.

O'Shea, T. J., M. A. BogAn, and L. E. Ellison. 2003. Monitoring trends in bat populations of the United States and Territories: status of the science and recommendations for the future. Wildlife Society Bulletin, 31: 16-29.

Owen, S. F., M. A. Henzel, W. M. Ford, B. R. Chapman, K. V. Miller, J. W. Edwards, and P. B. Wood. 2003. Home-range size and habitat used by the Northern myotis (Myotis septentrionalis). American Midland Naturalist, 150: 352-359.

Peakall, R., M. Ruibal, and D. B. Lindenmayer. 2003. Spatial autocorrelation analysis offers new insights into gene flow in the Australian bush rat, Rattus fuscipes. Evolution, 57: 1182-1195.

Perry, R. W., S. A. Carter, and R. E. Thill. 2010. Temporal patterns in capture rate and sex ratio of forest bats in Arkansas. American Midland Naturalist, 164: 270-282.

R Core TEAm. 2018. R: a language and environment for statistical computing. R Foundation for Statistical Computing, Vienna, Austria. Available at http://www.R-project.org/.

Rodhouse, T. J., P. C. Ormsbee, K. M. Irvine, L. A. Vierling, J. M. SzewCZAK, and K. T. Vierling. 2012. Assessing the status and trend of bat populations across broad geographic regions with dynamic distribution models. Ecological Applications, 22: 1098-1113.

Royston, P., and D. G. Altman. 1994. Regression using fractional polynomials of continuous covariates: parsimonious parametric modelling. Journal of the Royal Statistical Society, 43C: 429-467.

SAINANI, K. L. 2014. Explanatory versus predictive modeling. PM \& R, 6: 841-844.

SCHIElzeth, H. 2010. Simple means to improve the interpretability of regression coefficients. Methods in Ecology and Evolution, 1: 103-113.

Schirmacher, M. R., S. B. Castleberry, W. M. Ford, and K. V. MiLler. 2007. Species-specific habitat association models for bats in South-central West Virginia. Proceedings of the Annual Conference of the Southeastern Fish and Wildlife Agencies, 61: 46-53.

Sherwin, R. E., W. L. GANnON, and S. HAYMOND. 2000. The efficacy of acoustic techniques to infer differential use of habitat by bats. Acta Chiropterologica, 2: 145-153.

Steenweg, R., M. Hebblewhite, J. Whittington, P. LuKacs, and K. McKelvey. 2018. Sampling scales define occupancy and underlying occupancy-abundance relationships in animals. Ecology, 99: 172-183.

U.S. Fish AND WildLife Service. 2017a. Indiana bat summer survey guidance - automated acoustic bat ID software programs. Available at https://www.fws.gov/midwest/endangered/mammals/inba/surveys/inbaAcousticSoftware.ht ml. Accessed November 30, 2017.

U.S. Fish and Wildlife Service. 2017b. National Wetlands Inventory. Available at https://www.fws.gov/wetlands/ Data/Data-Download.html. Accessed November 28, 2017.

U.S. Geological Survey. 2019. National Wildlife Health Center — white-nose syndrome (WNS). 2019. Available at https://www.usgs.gov/ecosystems/invasive-speciesprogram/science/white-nose-syndrome?qt-science_center _objects=0\#qt-science_center_objects. Accessed July 22, 2019.

Verboom, B., and H. Huitema. 1997. The importance of linear landscape elements for the pipistrelle Pipistrellus pipistrellus and the serotine bat Eptesicus serotinus. Landscape Ecology, 12: 117-125.

Weller, T. J., and C. J. ZABel. 2002. Variation in bat detections due to detector orientation in a forest. Wildlife Society Bulletin, 30: 922-930.

Wiens, J. A., J. T. Rotenberry, and B. VAn Horne. 1987. Habitat occupancy patterns of North American shrubsteppe birds: the effects of spatial scale. Oikos, 48: 132-147.

Wilder, A. P., W. F. Frick, K. E. Langwig, and T. H. KunZ. 2011. Risk factors associated with mortality from whitenose syndrome among hibernating bat colonies. Biology Letters, 7: 950-953.

Wolbert, S. J., A. S. Zellner, and H. P. Whidden. 2014. Bat activity, insect biomass, and temperature along an elevational gradient. Northeastern Naturalist, 21: 72-85.

Zimmerman, G. S., and W. E. GlanZ. 2000. Habitat use by bats in eastern Maine. Journal of Wildlife Management, 64: 1032-1040.

Received 03 August 2019, accepted 03 February 2020 